\title{
Political Reforms as Religious Revival: Conceptual Foundations of Tanzimat
}

\author{
Alp Eren Topal | ORCID: 0000-0003-1217-0931 \\ Marie Skłodowska-Curie Fellow, Department of Culture Studies \\ and Oriental Languages; University of Oslo, Oslo, Norway \\ a.e.topal@ikos.uio.no
}

\begin{abstract}
Parallel to Arab Nahdah, Ottoman modernization program is associated with the Tanzimat, a period of drastic social, political and institutional transformation. The word tanzīmāt itself, however, merely means "regulations" or "reorganization" and very little has been done in investigating the conceptual or ideational foundations of Tanzimat reforms. The question at stake here is how these series of reforms were justified and legitimized within the Ottoman political culture. Accordingly, this paper focuses on reform debates among Ottoman bureaucrats and statesmen in the late eighteenth and early nineteenth centuries and proposes the concept and doctrine of tağdìd (renewal) as a key to understanding Ottoman reform and religious transformation. Ottoman reformers at the turn of 19th century resorted to the doctrine of centennial renewal in order to both criticize the moral shortcomings of Ottoman political system and legitimize innovation. Within this logic, Ottoman reformist sultans and politicians have frequently been referred to as muğaddids, that is restorers. This paper will present an account of the concept of tağdìd based on Ottoman political and historical writing from the period. I argue that Ottoman reform was inseparable from the logic of religious revival and that Ottoman debates should be considered as part of and discussed in relation to the 18 th-century Muslim revivalism which has attracted growing attention in the last decade.
\end{abstract}

\section{Keywords}

Tanzimat - Muslim revivalism - political reform - Ottoman Empire - Naqshbandiyya historicism - modernity 
On November 3 1839, Mustafa Reşid Paşa, the Minister of the recently established Foreign Affairs, read aloud an Imperial Edict at the Gülhane square quite close to the Imperial Palace. What must have been a relatively short event judging by the brevity of the text, would later be remembered as the proverbial beginning of Tanzimat, arguably the most significant era in Ottoman-Turkish modernization. A period of intensive political, legal and economic reforms as well as drastic cultural transformations, the Tanzimat is generally agreed to have ended at its zenith with the suspension of the short-lived Ottoman constitution, Kānūn-ı Esāsī, by 'Abdulhamid II in 1878. The four decades in between two constitutive texts, the Imperial Edict and the Constitution, witnessed an overhaul of the administrative system of the Ottoman State, integration of the Empire's economy into global capitalist system, successive separatist revolts by the various ethnic/confessional populations under the Empire's rule and last but not least the rise of a public sphere concurrent with the emergence of print capitalism and proto-national consciousness among both Muslims and non-Muslims.

It is not surprising therefore, that the Tanzimat has become a heavily loaded concept both in popular memory and historiography. Sometimes celebrated but more often condemned, Tanzimat has been associated with the experience of transition, liminality and the duality of institutions, practices and concepts between modernity and traditional frameworks. Both on the left and the right of contemporary Turkish politics, it is largely considered a failure due to the increasing separatist activity, ever-shrinking borders, gradual loss of statesovereignty vis-à-vis Europe, financial ruin and colonization of the Ottoman economy by global capitalism with destructive consequences. As Gürpınar demonstrates, while Tanzimat was initially regarded as an era of regeneration and renewal, it has come to be considered a naïve and largely failed experiment through successive historiographical interventions, particularly after the Second Constitutional era and during the early Republic. ${ }^{1}$

As 19th-century optimism waned, the idea of the Tanzimat was also discredited ... the Young Turks and subsequently the Kemalists demonized the Tanzimat to establish their legitimacy and demonstrate their vigilance by creating a diametrically opposite 'constitutive other'.

1 Gürpınar. Ottoman/Turkish Visions of the Nation 1860-1950. 164-19o.

2 Tondo. 164. 
Underlying both the historiographical accounts and the popular memory of Tanzimat has been a predominantly linear notion of modernization (as Westernization and secularization) and a teleological perspective, which passed judgment on Tanzimat as a prelude to the collapse of the Empire. Such linear and teleological narratives received barely any challenge up until recently. Tanzimat has been a curiously neglected topic in the historiography of the long nineteenth century with the late Ottoman historians focusing almost exclusively on the Hamidian Era and the Second Constitutional Era in an effort to explain the Empire's demise. Only in the last decade, a new wave of scholarship that takes Tanzimat as its focus has emerged with an attempt to understand the era on its own terms through revisiting available sources in a more self-reflective and methodologically driven approach. ${ }^{3}$

Still, however, there has been little attempt at studying how the Tanzimat a wide scale reform program that upended some centuries old practices and institutions was grounded in Ottoman political culture. There have been sporadic attempts at documenting and analyzing the reception of Tanzimat reforms among the Ottoman subjects. But as yet there exists no proper history of the conceptual framework of the Tanzimat let alone a detailed textual and conceptual analysis of the Imperial Edict of $1839 .{ }^{4}$ One reason for this absence is the conspicuous impulse to explain Ottoman modernization drive with reference to "enlightened" and "modern" ideas of a few prominent Ottoman bureaucrats who are imagined to be rowing against the currents of rampant conservatism. As brilliantly criticized by Olivier Bouquet, even the most erudite historians resort to singling out individual figures from the late eighteenth century ambassadors like Azmi Efendi to later bureaucrats like Mustafa Reşid Paşa as having properly understood the European model and possessing singular modernizing, westernizing and secularizing visions. ${ }^{5}$ Such accounts take modernization as axiomatic and paradigmatic, and also ignore the convoluted, complex and contested nature of political reform. Intra-elite factionalism, domestic conflicts and power struggles are ignored and reform is explained in highly teleological and linear interpretations which are then

3 See particularly Anscombe. "Islam and the Age of Ottoman Reform". 159-189; Şiviloğlu. The Emergence of Public Opinion; Koçunyan. Negotiating the Ottoman Constitution 1839-1876; Onaran. Padişahı Devirmek; Brisku. Political Reform in the Ottoman and Russian Empires; Türesay. "The Political Language of Takvîm-i vekayi".

4 Aylin Koçunyan's recent work is an exception although she focuses on the legal vocabulary of the Edict. See Koçunyan. Negotiating the Ottoman Constitution 1839-1876. 61-70.

5 Bouquet. "Is it Time to Stop Speaking about Ottoman Modernization?". 
superimposed on the individuals. ${ }^{6}$ One symptom of such accounts is that the seemingly traditional political language and concepts used in contemporary texts are simply explained away by reducing to a mere "lip service" and measly "legitimation strategies". Such an explanation implicitly assumes an unbridgeable gap between the language used and "actual intentions" of Ottoman actors and ignores the way politics is acted out in language. ${ }^{7}$ We need to be reflective of the difference between our analytical categories (as historians) and the concepts found in the sources, and focus our analysis on how the actors themselves conceptualized their actions and milieu, taking them seriously in the process. ${ }^{8}$

A proper conceptual history of the Tanzimat, therefore, should necessarily involve a meticulous disentanglement of several entangled semantic layers: 1) the conceptual framework behind the Tanzimat, that is, the semantic analysis of the Imperial Edict of 1839 with an eye to conceptual transformations preceding it; 2) elite and popular reception of Tanzimat throughout the nineteenth century and its calcification as a concept in Ottoman bureaucratic memory and particularly in the nineteenth century history writing; 3) historiographical narratives and popular myths that accumulated over a century and a half. While this is obviously a gargantuan task that requires significant archeological and genealogical work, one must begin somewhere. ${ }^{9}$ As such in this article, I would like to start with the first step: a conceptual analysis of what Tanzimat meant and in what kind of discursive framework it was located at the moment of inception and as it manifested in the Edict of 1839. How did the Ottoman bureaucrats conceptualize their reform attempts? How did they justify wide scale change and innovation both to themselves and their interlocutors? How did they imagine the past, the present and the future?

In the nineteenth century Ottoman context, the word tanzimant could be translated literally as "regulations" with legal and institutional implications. Although it is strongly associated with the Imperial Edict of 1839, the word is used only once in the document in a very basic sense, for the regulation of conscription (tanzìmāt-ı 'askeriyye). Since in the nineteenth century Ottoman writing the Edict is simply referred to as Gülhāne Hațt, the common reference to the Edict as Tanzimāa Fermānı seems to be a twentieth century attribution. There is, however, evidence that soon after its promulgation the Edict began

6 For a good criticism of such teleological approaches which also draws on the Russian example see Brisku. Political Reform. 1-17.

7 See also Topal. From Decline to Progress. 187.

8 See Topal and Wigen. "Ottoman Conceptual History".

9 For an in-depth discussion of archeological and genealogical work in the historiography of the Middle East see Topal and Wigen. "Ottoman Conceptual History". 
to be cited as the inception of Tanzimat. ${ }^{10}$ Moreover, terms such as tanzimant, tanzìmāt-ı hayriyye (auspicious organization), nizām-ı müstahsene (favourable order) and nizām-ı cedīd (new order) had been used in documents during the later reign of Mahmud II, in reference to drastic changes to the taxation system and regulation of conscription during 1830 . $^{11}$ The references to nizām-ı cedìd are our first clues that Mahmud's reforms and the Tanzimat were probably conceptualized as a continuation of Selim III's New Order project, which was interrupted in 1808 with the last major Janissary revolt.

Beyond this, the text of the Edict provides certain clues that are both conspicuous and, at the same time, easy to miss if one is not familiar with the development of reform arguments and concepts over the eighteenth and early nineteenth century. ${ }^{12}$ The Edict opens with the invocation of a hundred and fifty years of decline in power and wealth of the Empire and cites deviation from Sharia as the main reason for this decline. The Edict points out the necessity of issuing some new laws (kavānin-i cedìde) in order to ensure good government (hüsn-i idāre) and cites the circular logic between taxation, wealth and security. The document, then, proceeds to make several promises such as justice for all in court regardless of religious affiliation, ${ }^{13}$ fairer taxation, lighter conscription terms, putting an end to tax farming and due process in court. And finally the Edict recounts all these regulations as "Sharia law which is intended to revive the state, the religion and the community" (işbu ḳavāninn-i şer 'ïyye mücerret dīn ve devlet ve milleti ihya a için vażc olunacak ...) and also concludes that all the proposed changes amount to "wholesale transformation of the old methods and renewal" (keyfiyāt-ı meşrūḥa ușūl-ı atīkayı bütün bütün tag̀yir ve tecdìd demek olacagindan).

Some scholars have observed a paradox in this logic of the document. For instance, citing a nineteenth-century observer by the name James Porter, Şerif Mardin says "... it was indeed a curious document that could begin by 'imputing the decline of the Ottoman Empire principally to the transgressions of old laws,' proceed 'to adopt new regulations in the state,' and end by 'praising the

10 See for instance the chronicles of the nineteenth century chronicler Ahmed Lūtfĩ in Vak'anüvîs Ahmed Lûtfî Efendi Tarihi I.

11 Şimşek, The Grand Strategy of the Ottoman Empire 1826-1841, 235-37.

12 The transcribed text of the Edict can be found in many sources. All the translations throughout the paper are mine unless stated otherwise.

13 As an example of teleological interpretations, we should note here that the pervasive attribution of "equality" to the Gülhane Edict is simply a mistake. Although the Edict promises justice for all, there is no word or clause in the text that could be interpreted as equality. Equality (müsāvāt) becomes an issue only later, in the Reform Edict of 1856 . See Badem. "The Question of the Equality of Non-Muslims in the Ottoman Empire during the Crimean War (1853-1856)"; and Topal. "Ottomanism in History and Historiography". 
restoration of old manners and customs."'14 Mardin also concludes this "internal inconsistency" to be a mark of "a much more subtle and subterranean antagonism between the ideas that advocated a return to an Ottoman-Islamic golden age and the theories which sought to build anew better foundations for the tottering empire". ${ }^{15}$

I, however, argue on the contrary that the logic of the Edict is internally consistent in its articulation of reform and the key concepts to that logic are ihya (revival) and tecdìd (renewal). Both terms, but particularly tecdìd invoke the classical Islamic trope of centennial reform (Ar. tağdìd) within religion and a particular temporal logic associated with it. ${ }^{16}$ The doctrine, based on a prophetic hadith, takes it as axiomatic that the religious community will degenerate and fall into conflict every hundred years or so due to human nature and prophesizes that God will send forth a renewer (müceddid, Ar. muğaddid) to set the community and religion back on its right path. In the rest of the paper, I will demonstrate how the logic of tecdid emerged through reform debates in the New Order era and increasingly grew to be the most prevalent justification for Ottoman reform following the destruction of Janissary corps in 1827. I will argue that while this argument for renewal may have initially been just an argument to ward off the opposition, its logic actually found much resonance among the Ottoman literati who were heavily invested in understanding and explaining "Ottoman decline" since the early seventeenth century. Eventually, I will return to the Gülhane Edict to demonstrate the persistence of the logic of tecdid and I will conclude with some reflections on what this means for our understanding of modernization and secularization in the Ottoman context.

Another point that reinforces my argument for the centrality of the concept of renewal is Mujadddidi Naqshbandi support for the reform process. In a series of articles, Butrus Abu-Manneh had already demonstrated the spread of Naqshbandi networks in the Ottoman lands and Istanbul from the early eighteenth century onwards in several waves, and documented the prevalence of Naqshbandi affiliation among Ottoman grandees. ${ }^{17}$ Later, he noted the Naqshbandi influence on the Imperial Edict of 1839 through their networks

14 Mardin. The Genesis of Young Ottoman Thought. 196-197. Mardin himself quotes from Porter. Turkey. II: 24.

15 Mardin. The Genesis of Young Ottoman Thought. 197.

16 See Voll. "Renewal and Reform in Islamic History"; Rahman. "Revival and Reform in Islam"; and Haj. Reconfiguring Islamic Tradition.

17 Abu-Manneh. "The Naqshbandiyya-Mujaddidiyya in the Ottoman Lands in the Early 19th Century"; "Salafiyya and the Rise of the Khālidiyya in Baghdad in the Early Nineteenth Century"; and "Sheikh Murād al-Bukhārī and the Expansion of the Naqshbandī-Mujaddidī Order in Istanbul". 
among the bureaucrats. ${ }^{18}$ However, his observations have not made much impact on the historiographical reception of Tanzimat. Through the concept of tecdid, I demonstrate how Ottoman bureaucrats conceptualized reform in terms of Islamic renewal and revival. Finally, I contend that Ottoman reform at the dawn of modernity should be understood not only vis-a-vis state transformation that occupied Eurasian polities but also in the context of revivalist movements that marked Muslim geography from the South East Asia to North Africa and from the Najd to the Caucasus. ${ }^{19}$ While Ottoman debates did not include concepts such as taqlìd and iğtihäd which were central to the other ongoing debates, they still reveal a major concern with moral decline and regeneration as well as renewing the faith and tradition.

By the second half of the eighteenth century, Ottoman bureaucrats and statesmen increasingly called for military, financial and administrative reform. Beyond the immediate problems facing the Empire (particularly the growing challenge of Russia), such demands for reform also drew on a sense of imperial decline that had been gradually weaved and constructed by Ottoman scribes and chroniclers. From the late sixteenth century onwards and particularly through the crises-ridden seventeenth century many Ottoman intellectuals had interpreted the social and economic transformations of the Empire as a "dissolution of order" (halel or ihtila $l$ ) and a deviation from an idealized "ancient constitution" (kânūn-ı kadìm) imagined to be at work through the golden age of the Ottoman state from the reign of Mehmed II to the reign of Suleiman the Magnificent. ${ }^{20}$ In the second half of the seventeenth century, through the highly influential work of Kātip Çelebi (d. 1657) this particularly bureaucratic account of "dissolution of order" would evolve into a greater narrative of imperial decline. Particularly Kātip Çelebi's incorporation of Ibn Haldūn's model of the life cycle of states identifying the Ottoman state to be in the age of decline (sinn-i inhit $\bar{a}$ t t) had such a lasting impact that it

\footnotetext{
18 Abu-Manneh. "The Islamic Roots of Gülhane Rescript".

19 See particularly Haykel. Revival and Reform in Islam; Dallal. Islam without Europe; Spannaus. Preserving Islamic Tradition.

20 By now there is a sizeable literature on the seventeenth century reform literature. For an excellent overview see Sariyannis. A History of Ottoman Political Thought up to the Early Nineteenth Century, see in particular chapters 4 and 5; and also Topal. From decline to Progress. Chapter 1.
} 
triggered what modern historians call "Ibn Khaldunism in Ottoman letters". ${ }^{21}$ Not only would the historian Naima (d. 1716) incorporate Ibn Haldūn as the cornerstone of his famous chronicle but also Grand Mufti Pirizade Mehmed Sāhib would translate the first five books of Muqaddima into Turkish through 1720s. One key issue raised by Ottoman statesmen reading Ibn Hualdūn in the eighteenth century was whether Ottoman state was destined for collapse as suggested by the implicit determinism of Ibn Haldūn's model or whether it could still be salvaged through action. Demonstrating the immediacy and dimensions of the question of survival, we see a proliferation of treatises on the question of free will and predestination in addition to the recurrence of the problem in political writing, which Ethan Menchinger aptly attributes to the problem of reform and the fate of the Empire. ${ }^{22}$

It is on the background of such narratives and pressing questions that Ottoman bureaucrats engaged in a conversation on reform during the 1768 1774 Russo-Turkish War that shook Ottoman exceptionalism ${ }^{23}$ at its core. The urgency of the need for military reform gave impetus to search for new models and techniques in government and warfare, which eventually crystallized in the New Order program of Selim III (r. 1789-1808). Dozens of reform memoranda were written at the time addressing a plethora of domestic problems, as well as reports on European political and technical advancements by Ottoman ambassadors who were sent to various European capitals on ad hoc missions to observe and record. The sources provide us with ample material with which we can understand how reform was conceptualized. Among those, of particular attention is around twenty reform memoranda commissioned by Selim III in $1891 .{ }^{24}$

To list some of the expressions used by the memoranda writers: "to attain the ancient state and conditions" (eski hälin bulmak, tavr-ı kadimi bulmak), ${ }^{25}$ "a new kind of integration and order" (bir nev'i cedìd rābıța ve nizām, intizām itmek), ${ }^{26}$ "renewing the ancient order as it had been renewed in the past"

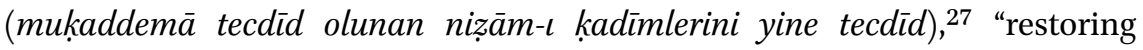

21 The extent and reach of Ibn Haldūn's influence on Ottoman political writing is still a continuing inquiry. For an up to date account see Sariyannis. "Ottoman Ibn Khaldunism Revisited".

22 Menchinger. "Free Will, Predestination, and the Fate of the Ottoman Empire".

23 On Ottoman exceptionalism see Menchinger. "Dreams of Destiny and Omens of Greatness".

24 Çağman, III. Selim'e Sunulan Islahat Layihaları.

25 Ibid. 5 .

26 Ibid. 59 .

27 Ibid. 78. 
the ancient law to its former glorious state" (kânūn-ı ḳadimelerinin hâalet-i $\bar{u}(\bar{a} s i n a$ ircāı $\iota) .{ }^{28}$

One of the first things one notices looking at these sources is the pervasive references to "ancient order" which would seem at odds with the novel practices and techniques proposed which were clearly inspired by the European model. The Ottoman state was announcing a "new order" and at the same time promising a restoration to the former glorious order of the Empire, which presents a puzzle quite parallel to the language of the Gülhane Edict I have noted above. Under the dominant paradigms of linear modernization and secularization, earlier scholarship pervasively dismissed this simultaneity of "old" and "new" as a mark of the legitimation strategies of the Ottoman Porte whereby traditional concepts were merely instrumentalized to dress up the novel ideas and practices against a conservative audience. ${ }^{29}$ Such an approach not only assumes an empirically untenable gap between the political language and the "actual" motivations of the reformers but also ignores the semantic transformation, dynamism and context-dependence of concepts however traditional they may be.

Fortunately, particularly in the last decade, the late eighteenth century and New Order era has received significant attention in scholarship, and by now, there is a sizeable literature on the debates and issues of the period. ${ }^{30}$ Among those, Ali Yaycıoğlu's seminal article is particularly noteworthy since it forces us to radically rethink New Order politics. Yaycıoğlu challenges the conventional approach which presents a conflict between "Westernized reformers" and "Muslim conservatives" and shows how, on the contrary, New Order was a broad coalition "two major components of which were the Euro-Ottoman military engineers and Sharia-minded Islamic activists, acting against the entrenched (and local) social, military and religious order that was guarded by the Janissaries and groups that gathered around them". ${ }^{31} \mathrm{He}$ particularly emphasizes the role of Mujaddidi Naqshbandi networks and their revivalist ethos in the reform effort which targeted the "pious antinomianism" of the Janissaries who saw themselves as "guardians of tradition". Yaycıŏlu's account indicates that the conflict at stake during the New Order era was

\footnotetext{
28 Ibid. 8o.

29 See in particular Berkes. The Development of Secularism in Turkey; Shaw. Between the Old and the New; Beydilli. "Küçük Kaynarca'dan".

30 See particularly Aksan. An Ottoman Statesman in War and Peace; "Ottoman Political Writing 1768-1808"; Şakul. "Nizâm-ı Cedid"; Menchinger. The First of the Modern Ottomans; Yeşil. "Looking at the French Revolution through Ottoman eyes"; Yaycığlu. "Guarding Traditions and Laws".

31 Yaycıoğlu. "Guarding Traditions and Laws". 15-44.
} 
not conceptualized as merely a conflict between "tradition" and "innovation", rather it must have been a conflict between competing concepts of tradition and bids for legitimacy through different genealogies. Here, I will demonstrate how different conceptions of tradition and innovation are clearly reflected in the political writing of the period produced by bureaucrats belonging to different ranks of Ottoman state.

New Order debates reveal an ongoing contestation over what constitutes the Ottoman-Islamic tradition, with different authors taking different positions within a continuum. The proposal of imitating the European military technologies and restructuring the military creates a tension between the reformist camp and the janissary alliance who perceive it as a threat to the status quo. This and the fact that novelty and innovation had to be negotiated and justified makes not only the importation of European technologies but also every reformist attempt by the palace a conceptual problem which was not exclusive to the late eighteenth century. The distinction between what is kadim (ancient, established) and what is hädis or bid'ah (innovation or invention in a derogatory sense) was a core element of Ottoman-Islamic legal and political tradition. ${ }^{32}$

Opposition to the New Order instrumentalized this tension and labelled the adoption of European military techniques and technologies as bid'ah and

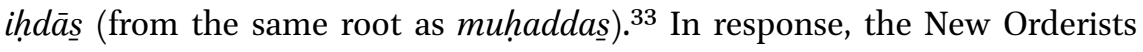
defended their efforts as tecdid. The language of the memoranda does not put the new (cedī $)$ and the ancient ( $k$ adim) as a binary opposition; instead the act of renewal (tecdid) has an organic connection to what is ancient. Minor exceptions aside cedìd and tecdìd had not been used as key concepts in political context before in Ottoman texts. ${ }^{34}$ It is possible to encounter in any kind of text the word tecdìd being used in the very basic non-political sense of renewal, i.e. renewal of a contract and agreement, renewal of a marriage after a divorce, renewal and renovation of a building. As noted above, what stood against kadim semantically was the words hädis and bid'ah, both denoting undesirable innovation, the latter being a more technical term in Islamic scholarship. Cedid and tecdid here appear to have been consciously chosen to counter the accusations of bid'ah and ihdās as favourable words. The word invokes the concept

32 See Sariyannis. A History of Ottoman Political Thought. 444-447.

33 See Kuşmânî. Zebîre-i Kuşmânîfi Nizâm-ı Ilhâmî. 10.

34 There are some attempts at regulating land and tax regimes in the late seventeenth century that were called ḳānūn-ı cedìd and there is evidence that Köprülü Fazıl Mustafa Paşa's tax reforms around the same era were called nizām-ı cedīd. Yet, further research is needed to explore the context and meaning of this conceptual clustering a century before the New Order reform program. 
of periodic reform in Islamic tradition, which postulates gradual degeneration and dissolution over time due to human error and foresees the necessity of renewal and regeneration of the tradition through human agency.

The doctrine of tecdid is based on a particular hadith which says "God will send to this community at the turn of every century someone (or: people) who will restore religion". ${ }^{35}$ Based on this hadith, there emerged in the second Hijri century a vague tradition which predicted one exceptional scholar, a renewer (Ar. muğaddid, Ott. müceddid) to arise around the turn of each century and renew the religious tradition and doctrine by resolving the contemporary problems, debates and controversies and reinvigorating religious zeal. Although there has never been a solid consensus on the particular renewers of each century, the names who were circulated were exclusively scholars, meaning legal scholars philosophers, Sufis, or exegetes. However, from the 16th century onwards, in the Ottoman vocabulary, we observe the word being used for Ottoman sultans as well. For instance Selim I, Suleiman I ${ }^{36}$ and Murad II, ${ }^{37}$ had all been designated by the title in some way. As pointed out by both Fleischer and Felek, the image of the renewer and restorer, brought together in the political ruler instead of the scholar, carries strong connotations of Messianism, especially when one considers Suleiman I and Murad III's reigns coincided with the end of first hiğrī millennium. This Messianic trend apparently resurfaces in the late eighteenth century context in the face of crisis. Several grand viziers of the late eighteenth century such as Koca Ragıp Paşa and Halil Hamid Paşa were expected to be renewers as well. ${ }^{38}$ Apparently, Ottoman bureaucrats also saw a restorer in Selim III. Menchinger notes that the official chronicler of the period, Ahmed Vāsıf Efendi, a staunch supporter of reform himself, refers to him as the "man of the century" (șâhib-imi'a), another term for müceddid. ${ }^{39}$

It is no wonder that, from the start, the opposition to the reform movement also took issue with the title of the renewer as well. An anonymous notice left in front of a public fountain in Istanbul, in early 1789 , during the heat of another Russian campaign, accused Abdulhamid I of losing territories to the Russians

35 Ethan Menchinger is the first scholar to make the connection between reform and this particular tradition in the case of Ahmed Vasıf Efendi, see his An Ottoman Historian in an Age of Reform. 229-231; and Menchinger, The First of the Modern Ottomans, 86, 212. For the tradition of cyclical reform see Landau-Tasseron. "The 'Cyclical Reform".

36 See Fleischer. "The Lawgiver as Messiah". 161.

37 Felek. "(Re)creating Image and Identity".

38 Menchinger. An Ottoman Historian. 71, 229-30.

39 Ibid. 229-3o. 
and causing the ruin of soldiers in the war effort. ${ }^{40}$ The author who calls himself ocaklı (a member of the janissary corps) openly threatens the Sultan with counter-action - a dethronement is heavily implied, if not regicide - if he does not declare peace and call the troops back from the campaign. He accuses the viziers, the grand mufti and the other officials for misinforming the Sultan and questions their Muslimness. He blames the Sultan for oppressing the ummah and says they do not want a renewer (müceddid) vizier or grand mufti, openly questioning the legitimacy of the category and obviously mocking the reform attempts.

We should note however that the reformers themselves had suspicions and misgivings about the legitimacy of innovation and the boundaries of tradition. Some of the memoranda reflect these suspicions very clearly. For instance chief treasurer Mehmed Şerif Efendi, after suggesting some venues of reform briefly, warns that the principle of tradition should not be violated:

... as the principle goes "our religion is not based on reason ['ukül] but tradition [nukül]" and hence not everything we conceive is beneficial and advisable. In any case it needs to be congruent with venerable Sharia. It is obvious that any policy and order not congruent with Sharia will not only prove useless but also will yield material [șūrī] and spiritual [mānevī] damage ...41

While not directly challenging reform attempts, Şerif Efendi still perceives a tension between what is to come in the name of reform and whatever it is that he considers the religious tradition. Şerif Efendi thus takes a hesitant and cautious position with respect to reform; he endorses it and yet suggests caution fearing that tradition may be violated. Another anonymous memoranda writer expresses his concern in a more direct albeit cynical way, framing military reform as adopting French habits:

... it is possible to train soldiers who can face the enemy in battle, yet only on the condition that it must definitely not be revealed to the soldiers and the commoners that they will be adopting the French form [tavr-ı efrenc] which is contrary to our disposition and customs. They should be told something like "the Sultan is doing a favour to his regiments and he will restore the ancient practices [resm-i kadim] and this is what

40 See Sarıcaoğlu. "Osmanlı Muhalefet Geleneğinde Yeni Bir Dönem".

41 Çağman, III. Selim'e Sunulan Islahat Layihaları. 21. All the translations are mine unless stated otherwise. 
is necessary and Islam is all encompassing anyway" And although what is desired is the application of the French arrangements, French military terms should not be adopted and must be replaced with Turkish words. ${ }^{42}$

Thus, the anonymous author not only reveals his misgivings regarding the legitimacy of reform but also he betrays the general concern of the reformers about communicating the program to commoners. In contrast to many others who advocated and justified adoption of Western techniques as legitimate "retaliation in kind" (mukāabele bil-mis $)^{43}$ this anonymous author considers military reform as "adopting the European form". Interestingly, however, even this cynical author justifies the emulation by distinguishing between form and principles and arguing that reform will work as long as form (etvār) changes and principles (ușūl) remain (ețvār değişüb ușūl değişmemek ile olur) ${ }^{44}$ Thus, he resolves the tension between preserving tradition and justifying innovation, by splitting the Ottoman way into formal and essential halves.

We come across a comparable criticism later in the New Order program, in 1806, by one Ömer Faik Efendi who cautiously criticizes the New Order overall without brushing it aside completely. He approves of the military reform but still warns that:

As is known to all, the Exalted State is a state based on Sharia and hence when setting out to some business it should be referred to Sharia and consulted with the God-fearing pious people. One should abstain from inventions [muhaddes $\bar{a} t$ ]; indeed it is preferable to reinforce the constitution of the state by repairing and renewing [tecdid] those orders of the past [nizämlar], that is kanūn and shari'ah, which have been dissolved with the passage of time. ${ }^{45}$

Ömer Faik Efendi is obviously torn between the necessity of renewal and the dangers of innovation. He echoes the concerns of one of the memoranda writers mentioned above when he accuses the regulations of the New Order with rootlessness and being based solely on reason (nizāmlarda mebde olmayub yalını 'akla teba'iyyetle mübādere olunmaginn). He conceptually solves the tension by classifying the New Order measures into two: substantial/spiritual

\footnotetext{
$42 \quad$ Ibid. 9 .

43 See in particular Menchinger. The First of the Modern Ottomans. 87, 201, 239.

44 Çağman. Selim'e Sunulan Islahat Layihaları. 10.

45 Sarkkaya. Ömer Fâik Efendi, 5. For Ömer Faik Efendi's treatise see also Şakul. "Nizâm-ı Cedid". 145-47 and Beydilli. "Küçük Kaynarca'dan". 37-40.
} 
(mānevī) and formal (șūrì). Accordingly, military, financial and administrative measures are the formal measures, pertaining to the materiality and religious measures which pertain to spirituality. He brings criticism for both categories yet he is particularly concerned about the substantial/spiritual measures; he thinks religious scholars and pious people do not get the necessary respect and attention. ${ }^{46}$ This distinction also echoes that of the anonymous memoranda writer between form (țavır) and essence (ușül). By drawing a line, one distinguishes between what may be subject to change and what should not, which, in the end, boils down to an intuitive distinction between form and substance.

The strongest defence of the New Order program as renewal in religion comes from a wandering Naqshbandi preacher, Ubeydullah Kuşmānī, whom Yaycıoğlu particularly highlights as the node that brings together the puritanical revivalism and political reform. ${ }^{47}$ Kuşmani pens a whole treatise (ca. 180o) defending Selim III's New Order and military reforms, and at the same time openly attacking the janissaries in a heavily derogative language for their unruly behaviour, ignorance and their penchant for sin and pleasure. ${ }^{48}$ The treatise is a defence and justification of the principle of mukābele bil-misl and obedience to the ruler in general, with frequent references to the Prophetic tradition (hadis $\underline{\text { s }}$ ) and particular verses from the Quran. He particularly counters the accusations, by the Janissaries, of innovation and invention by citing the aforementioned hadith and invoking the doctrine of the centennial renewal. ${ }^{49}$ Kuşmānī argues that what is being done is none other than tecdìd and ihy $\bar{a}^{50}$ and considers mukāabele bil-mis l a religious obligation ( farż). ${ }^{51}$

We must note once again that religious renewal was not merely a convenient argument for the New Order program; as emphasized by Yaycığlu, moral and religious revival as part of disciplining the society was a significant element of the reform attempts. The reform program not only proposed the reform of religious institution, but also involved a serious argument against the observed moral laxity within Ottoman society, which was expressed with reference to a moral ideal, which increasingly incorporated a Sunni orthodox

46 Sarıkaya. Ömer Fâik Efendi. 12-13.

47 See Yaycıoğlu. "Guarding traditions". 1591-97 who provides very interesting details of this enigmatic figure. Also see Şakul. "Nizâm-ı Cedid”. 135-39; Beydilli. "Küçük Kaynarca’dan”. 35-37, and Sariyannis. A History of Ottoman Political Thought. 414.

48 See Kuşmânî. Zebîre-i Kuşmânîfi Nizâm-ı Ilhâmî. 11-12.

49 Ibid. 4.

5 o Ibid. $7,60,84$.

51 Ibid. 23 . 
position associated with Sharia, akin to the one observed in the seventeenth century Kadızadeli challenge. Frequent complaints about moral laxity, lethargy and apathy and calls for moral uprightness as a prerequisite of reform were not simply restricted to the men of government who were supposed to shoulder the reform attempt. Observable in the reform memoranda is an emphasized concern for moral subjects overall, which is expressed in terms of religious piety.

The failure of the New Order program in 1808 after a violent Janissary revolt put an end to these debates for a while. However, as I will demonstrate below, the debates around legitimacy of reform and renewal picked up after the abrogation of Janissaries in 1826 by Mahmud II, who initiated another reform program, which again relied on the premise of tecdidd.

\section{$3 \quad$ After Janissaries: Now What?}

Mahmud II's earlier years focused on curbing the power of ayans particularly in the Balkans which eventually led to the Greek Revolt that shook the Empire to its core. In what Şükrü Ilıcak called a "radical rethinking of empire," Ottoman elite started questioning the basics of their lifestyle by following the Haldūnian logic, which associated decline with sedentary lifestyle. ${ }^{52}$ Ilıcak shows, how in an effort to explain the inability of the Empire to counteract against the Greek rebels, both the Sultan and the divan members referred to the Greeks as the bedevis (nomads) and attributed the lack of zeal and indifference among the Muslim population to hadāriyet (sedentary/urban life). The obvious solution was to invoke, once again, among the Muslim population the spirit of bedeviyet (nomadism), in order to facilitate mobilization (seferiyet) of the population against the Greek insurgents..$^{53}$ Accordingly, the state distributed a huge number of rifles to local Muslims and encouraged them to own horses and carry daggers all the time, the statesmen, ulema and other dignitaries were also encouraged to do the same and discouraged from displaying the symbols of hadāă life style, i.e. giving up flamboyant and luxurious clothing and donning simple garbs, avoiding extravagance in all things and especially excessive food and alcohol consumption. ${ }^{54}$ Ilıcak particularly emphasizes the disappointment and frustration, frequently expressed in

\footnotetext{
$52 \quad$ Ilıcak. A Radical Rethinking of Empire. Chapter 2.

53 Ilıcak. A Radical Rethinking of Empire. 122-123.

54 Ibid. 153-154.
} 
Mahmud II's letters, with the disinterest and inertia with which the Muslim population met one of the gravest crises of the Empire. ${ }^{55}$ This episode demonstrates both the desperate quest for directions of reform and the cyclical logic parallel to renewal with which Ottoman reformers operated. However, this was a brief episode and as I will demonstrate further, after the abrogation of the Janissaries, the argument for renewal took on a different colour which was more receptive to innovation.

The destruction of Janissaries and the establishment of the new army through mass conscription marks the end of a long era in Ottoman politics. With Janissaries gone, the ulema lost their allies in challenging the authority of the palace. Mahmud II further curbed the power of the ulema by transferring the control of pious foundations to the state, thus restoring virtually all economic and hence, political power to the palace. As Gültekin Yildız aptly concludes, what Mahmud II achieved was a restoration par excellence rather than simple reform. ${ }^{56}$

Not surprisingly destruction of Janissaries, the so called Auspicious Affair (Vak'a-yı Hayriyye) was also legitimized with reference to doctrine of renewal. In his account of the affair commissioned by Mahmud II himself, Mehmed Esad Efendi hails the sultan as the real renewer of the century (müceddid, re's-i mi'e) after his success in abrogating the janissary corps. He allocates a separate chapter to exploring the doctrine of renewal in his chronicle of the events leading to and following the abrogation of the janissaries, and starts by citing the same hadith. ${ }^{57}$ And citing classical sources, he argues that "tecdid is all about distinguishing between sunnah and bid'a, expanding the knowledge, honoring the men of knowledge with support and sponsorship as well as belittling those who engage in bid'a and destroying them". ${ }^{58}$ Hence, for Esad Efendi, tecdid refers not only to a scholarly act of reform within tradition to revive the religion, but also a political act aimed at rooting out sedition and heresy. No wonder then, he goes on to cite several classical sources to argue that the renewer of the century does not have to be one of the fuqah $\bar{a}$; it could actually be the uli al-amr, the political authority to whom the ummah obeys. Because, he contends, without the power of the ruler to enforce right and wrong, Sharia would not mean much; protecting the religion essentially requires the power to enforce which is the prerogative of rulers. ${ }^{59}$ Then he goes on to do some

55 Ibid. 117 .

$5^{6}$ For an excellent discussion of the implications of Mahmud II's restoration project see Ylldız. Neferin Adı Yok. 15-130.

57 Es'ad Efendi. Üss-i Zafer. 138-145.

58 Ibid. 139 .

59 Ibid. 140. 
calendar calculations to prove through birthdates that Mahmud II is indeed the renewer of the century.

Later, the vocabulary of renewal and the renewer was further and frequently used in the Ottoman official gazette Takvīm-i Vekāyi (1831-) as Özgür Türesay's recent analysis clearly demonstrate. ${ }^{60}$ Türesay notes how Takvim presented the reform process as tecdìd-i usūul-i devlet (renewal of the foundations of the state) or teceddüdāt in plural, and Mahmud II as the müceddìd-i kavāninn-i devlet (renewer of the laws of the state). He also highlights how Takvim recognized the novelty of some of the policies but still framed these as part of the renewal process whereby formerly fragmented and disaggregated elements of the order was bound to a single principle ( $k \bar{a} \bar{c}^{i} \mathrm{ide}-i \mathrm{v}$ ăhid), which is obviously a celebration of the centralization of the state power. Interestingly, Türesay also notes that, Takvim labels the reforms carried out by Mehmed Ali of Egypt as ihtirā $\bar{a} t$ ve bid'ât (illicit innovations and inventions).

Considering that Mehmed Esad Efendi, who worked like a propaganda minister for Mahmud II, was the founder and the first editor of Takvim, there remains the question of how far this vocabulary of renewal was shared among Ottoman officials. However, there are other works from the era which give us ample clues as to how Mahmud's reforms were framed. Particularly, the reform memorandum written by Keçecizade Izzet Molla ${ }^{61}$ in 1827 , shortly after the destruction of Janissary corps, is one of the most revealing accounts of what kind of problems Ottoman statesmen were grappling with. Keçecizade, who was a Naqshbandi affiliate, ${ }^{62}$ writes in a polemical style answering a host of questions posed by imagined interlocutors, presents a scathing criticism of the Ottoman state apparatus and proposes various items of reform.

Keçecizade opens his treatise by invoking the problem of decline (inhițatat), warning against fatalist arguments and reminding the readers their personal

6o Türesay. "The Political Language of Takvim-i vekayi". Takvim was hitherto ignored by scholars due to the contention that it was simply a continuation of official chronicling in newspaper form and hence it would not offer much else than a dry account of official policy decisions. Türesay, however, demonstrates the benefits of studying Takvim for our understanding of the political language of the period, since the official gazette was "primarily a propaganda instrument at the service of political authority [...] intended for the production and dissemination of a discourse framing and legitimizing the centralizing reforms undertaken since 1826 ".

61 Doğan, Keçecizâde Izzet Molla'nın Islah-ı Nizâm-ı Devlete Dâir Risâle Adlı Eserinin Transkripsiyonu ve Edisyon Kritiği. Keçecizade Izzet Molla has been a popular figure in the study of Ottoman poetry due to his innovative style and substance. His political writing, however, seems to have been mostly neglected despite his key role in certain political crises of the period. For an exception see Beydilli. "Küçük Kaynarca'dan". 58-62. 
responsibility in reform by giving the Habsburgs as an example. ${ }^{63} \mathrm{He}$ also rebuts those who argue that Frankish ways and the Ottoman ways are not compatible (ușūl-ı efrenciyyeye bizim ușūlümüz muġāyirdir) and puts forward Egypt as an example who was revived by an Ottoman vizier even after the French invasion. ${ }^{64}$ Yet, he is not overly optimistic about the prospects of reform either; Keçecizade argues that something has gone clearly wrong with the Ottoman way:

The question is who will do all this? Our answer is "we will do it by God's support". There are so many states who have established order in their realms; there are no instances of deputies from one state going to another to establish order. It is up to the deputies of that realm in any case. Our own deputies are not possessed or traitors, thank God, but since our ways (ușūl) are corrupt, it would not make a difference even if we had Aristo or Plato here. It took us forty years to convince people of the benefit of the issue of military drills (madde-i ta'lim), an issue which is clear as day.... Besides the matter of religion, the order of the infidel states are better than the Islamic state, as in the issue of military drill. That is because, unbelief is constant in its creed and hence they have established order in their world. We, on the other hand, are not loyal to our creed, and not constant in our practice. ${ }^{65}$

We see a minor shift of vocabulary here: the suggestion that what is corrupt is actually $u s ̦ u \bar{l}$, not anything else; Ottoman way itself is corrupt. Ușül is a difficult word to translate, it can mean either principles (foundations and sources) or method, or both at the same time. As I have noted above, a late eighteenth

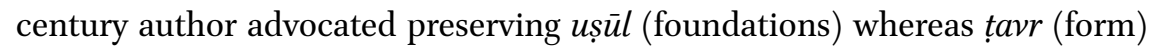
could be changed. Keçecizade, on the other hand, in an effort to explain the systemic, structural problems of the Ottoman state puts the blame on a corrupt $u s ̦ \bar{u} l$ and advocates a return to Sharia:

What do we have the siyāset-i şeriyye for [if we are not going to use it]? Once we change our ways $[u s ̦ \bar{u} l]$ and all the issues are bound to the way of the New Order [ușūlı Nizâm-ı Cedìd], with the auspice of the glorious

63 Doğan, Keçecizâde, 7 .

64 Ibid. 8.

65 Ibid. 11-12. 
Sharia ... The order that is from God is not spoiled easily. Right is triumphant and nothing may trump it. ${ }^{66}$

Although Keçecizade invokes the New Order program as being still in currency, his argument goes one step further than that of the New Orderists in emphasizing that there is something rotten in the way things have come to be with the Ottoman state and the solution is proper application and execution of Sharia. Another difference is that while the New Order literature (and the literature of earlier centuries) emphasize the poor moral standing of the men of the state and the people as the cause of lack of order and present order as something to be achieved as a result of and maintained through moral responsibility, with Keçecizade we see a partial reversal of the equation: lack of order may also lead to moral corruption; one cannot have good moral subjects with a corrupt system.

The instrumentality of the vocabulary of Sharia becomes apparent at this point: proposed as an abstract set of politico-moral principles, Sharia allows both a criticism of Ottoman way/system/tradition through broader Islamic precepts and also again as an abstract set of principles it allows legitimation of the European administrative and military practices to be imported. Thus new order gains a clearer meaning: ridding the Ottoman ancien régime of its corruption and building a new order on the principles of Sharia which are "compatible" with rational practices of the Europeans anyway.

The concept of order as a set of regulations and principles $(u s ̦ \bar{u} l)$ emerges even more clearly after Keçecizade's ridicule of some of the more literal interpretations of a call for restoration:

As Na'ima had responded to Üstüvānī, the ulema and the bureaucrats of this grand dynasty cannot walk around naked like the desert Arabs. We respond to the ignoramuses who say "it was like that once" that equity and fairness would be achieved if every class was content with [how it was in] the earlier times. [The difference between] our times and the earlier times may be seen if one looks at the gravestones in Üsküdar [as an example]. Something which has reached this stage cannot be returned to its earlier state. But one can issue a ban through Sharia by reasoning that over-decoration of the gravestones are harmful to both the deceased and his inheritors. Yet one cannot ban all gravestones as harmful innovation and even if one does, it is not worth it. Similarly, since it is not possible to revert each class to that former state, we should strive to care for its order 
as much as possible following the dictum of "do not completely abandon one thing, if you cannot conceive it completely". Otherwise the objection of the fool is against all classes. If you say "let us organize each class like as it was before", that is not reasonable either, for the land allotment of the grand vizier during Sultan Suleiman's time would not be enough even for the quiver carrier today. Hence, Sultan Suleiman did not imitate Umar ibn Abd al-Aziz, and he, in his turn, did not imitate Umar I. The point of order is to improve upon present and not let the situation fare worse at least. Otherwise, the kind of correction of the world demanded by the people is not possible. Our desire is that bribery - that destroyer of the world is abolished, our income is preserved, our magistrates and viziers be content with their allotments and they do not commit injustice, and Sharia-abiding regents are appointed and an order is established which is at least better than that of the $40-5$ o years before. ${ }^{67}$

In this passage Keçecizade tackles several different issues at once and reiterates the doctrine of renewal. The argument about clothing is clearly directed against the more literal arguments for simplicity and frugality that emerge in the early nineteenth century, which manifested itself as official state policy during the Greek revolt as a return to bedeviyet. By invoking the example of gravestones, Keçecizade equates this approach with Wahhabi Salafism. Wahhabism had emerged as a revivalist movement in Najd in the late eighteenth century and challenged the Ottoman rule on both religious and political grounds. One of the main markers of the movement was their rejection of gravestones and visiting of the tombs (including that of the prophet) as harmful innovations (bid'ah) and idolatry, a reaction which Ottomans found extreme.

Keçecizade similarly rejects arguments for a full reversal and total imitation of ancestors for reforming the social estates as ridiculous and foolhardy proposals, which comes out as a criticism of the debates of the New Order era. The optimist projections of the previous literature are also gone; he does not consider a full revival possible and suggests a humbled and controlled reform process which emphasizes prevention of extravagance, austerity, frugality and law-abidance. Hence, revival is not about imitation (taklied) of past practices but the principles and laws underlying these practices, namely principles of Sharia.

Reforms proposed by Keçecizade boil down to the organization of the central bureaucracy and the religious institution and mainly their status and salaries. In spite of his argument for compatibility between Sharia and the

67 Ibid. 6o-61. 
European ways, there is little in his concrete proposal that could be taken as an imitation of the Western ways. Still, however, closing his memorandum he feels the need to reiterate that what is at stake is not innovation or novelty but tecdid:

These principles and methods, thus written, look like some new laws [kavāninn-i cedìde] and a bunch of regulations [nizāmaāt-ı 'adìde] at first glance and to the gaze of the fool and as such may disturb the minds of some. Observed with a meticulous eye, however, they are all about the renewal [tecdīd] of the old laws [kavānin-i 'atīka] of our Exalted State ... Either we take this approach or stay the way we are now. There is no middle ground. 68

These closing remarks bear striking resemblance to the conclusion of the Edict of 1839 cited in the introduction which states that the proposed changes amount to a "wholesale transformation of the old methods and renewal" (... keyfiyāt-ı meşrūha ușūl-ı 'atīkayı bütün bütün tağyı̈r ve tecdīd demek olacağından ...). Besides the concept of tecdìd, the use of the phrase ușül-ı 'atīka in the Edict is meaningful in two ways: first, the use of 'atīk (old) instead of kadim (ancient, revered) maintains the reverence for tradition while condemning the past. As opposed to kadim which attributes a positive value and a sense of reverence to anything it designates by virtue of coming first and being foundational, 'atīk simply means old. Second, use of ușūl instead of kānūn or nizāmm again puts the blame on practices and methods that has been in effect instead of traditional values, principles and codes, which is quite congruent with Keçecizade's argument that Ottoman $u s \underline{u} l$ was corrupt due to deviation from norms, that is Sharia. The Edict, hence, proposes throwing away the practices of the old, that is the past hundred and fifty years which mainly includes tax-farming, unjust taxation, monopolies, confiscation, and recently unfair conscription and promises religious law which will rejuvenate the state, the religion and the nation (işbu kavāninn-i şeriiyye mücerred din ve devlet ve milleti ihya için vażc olunacak ...), which is again summed up in the concept tecdid.

Keçecizade died in 1829 in exile, a full decade before the drafting of the Edict. However, as I have also noted with the vocabulary of Takvim, the conceptual framework of tecdid continued to dominate official language. This is also corroborated by Butrus Abu Manneh's observations on the Edict noted above. ${ }^{69}$ Ali Yaycıoğlu's argument for a puritan revivalism through Naqshbandi

68 Ibid. 73 .

69 Abu-Manneh. "Islamic Roots". 
support to the New Order and the continuity in the use of the concept of tecdid complement Abu Manneh's account and demonstrate the logic of renewal underlying the Edict.

In this paper, I have demonstrated the centrality of the logic of centennial renewal and reform to the Ottoman political language at the dawn of modernity and how the same logic underscores the Gülhane Edict of 1839 which has, so far, been interpreted within the rather linear frameworks of modernization and secularization. This raises us to rethink two issues: secularization and modernization.

First question is of course with regard to secularization and the role of religion in the formation of Ottoman modernity and the conceptual problem here requires us to tackle the question of Ottoman Islam prior to modernity. That is necessary, because the bulk of the literature on the modern era drastically caricaturizes the character of Ottoman Islam prior to modernity and its relation to politics. This is evident in the arguments for a "politicization of Islam" in the modern era. ${ }^{70}$ We need to realize, however, that Islam was highly politicized and its meaning almost always contested before modernity, as the brilliant scholarship on Ottoman "confessionalization" has repeatedly emphasized. ${ }^{71}$ While the patterns of religious conflict in the early modern era is too complex to summarize here, Sunnification of Ottoman Islam as a consequence of both Ottoman-Safavid rivalry and also the Kadizadeli challenge needs to be kept in mind. As Yaycıoğlu also describes ${ }^{72}$ Ottoman reformers in the New Order era seem to have embraced the puritanical challenge of earlier religious movements such as the Kadızadeli's and used it against the antinomian janissaries, in alliance with the Naqshbandi's and their revivalist ethos.

New Order era set the stage and the example in presenting social and political reform as inseparable from religious revival by invoking the ancient doctrine of periodic renewal in Islam. This trend continued during the reign of Mahmūd II and early Tanzimat as well and state monopoly over religious discourse was established particularly with the isolation of the ulema from their previous bases of power. Reforms leading up to the Tanzimat and the Edict was justified in again the language of renewal, while as we have seen particularly

$70 \quad$ Most notably see Karpat. Politicization of Islam.

71 See particularly Krstic. Contested Conversions to Islam; Erginbaş (ed.). Ottoman Sunnism.

72 Yaycı̆̆lu. “Guarding”. 1578-83. 
with Keçecizade, more fundamentalist conceptions of reform were rejected. Condemnation of Ottoman past through eternal and immutable principles of Sharia reached its peak during this period with the Edict proclaiming the overhaul of old ways in favour of Sharia and renewal. Some scholars have chosen to call this process "Islamic modernization" 73 but such a label takes Islam to be a mere "catalyser" in the process and misses the subtle reconfigurations Islamic tradition went through and the expansion of concepts in an effort to come to terms with European progress. Naming this process Islamic modernization or politicization of Islam does injustice to the fluidity of the Ottoman-Islamic tradition by implying a reduction of Islam to newly emerging orthodoxies. Instead, one might see this process as a transformation of Islam, and formation of new orthodoxies as well as rooting out of alternatives.

This does not mean, however, that we have to completely do away with the secularization argument. Although scholars have seriously criticized the secularization paradigm recently, ${ }^{74}$ I believe there is still reason to think about secularization in a more nuanced frame. Because, the evidence clearly demonstrates a transformation in the language, concepts, and the way "the political" and "the religious" were redefined in the process of reform not least through redefinition of orthodoxy and further subjugation of religious institution to political control of the government. The revivalist ethos of the Naqshbandiyya, the reformist drive of the bureaucracy and Mahmud II's desire for restoring power to the palace all relied on the discourse of tecdid, reaffirming the primacy of faith and Sharia, and condemning the antinomian Janissary opposition as heresy. Still, these nodes did not align neatly. Mahmud did not believe in sharing his authority and he certainly did not trust the Naqshbandiyya. The efforts of Mehmed Esad to reframe tecdid as a political act and present Mahmud as the renewer betrays both a rivalry with Muhammed Ali and also with the spiritual authority of the Naqšabandī. Such an absorption of puritan challenges and reaffirmation of temporal authority closely resembles the development of the concept of the sultanate and caliphate in the first three centuries of Ottoman rule in Anatolia, whereby the sultanic authority was redefined in reaction to the challenge of the mystical authority of the religious movements. ${ }^{75}$

Another aspect of secularization question is the temporalization of Islam and emerging historical consciousness that we observe around the reform debates, which bring us to the second question: modernity. In a recent work

73 See for instance Şakul. "Nizam-ı Cedid".

74 See for instance Kırmızı. "19. Yüzyılı Laiksizleştirmek: Osmanlı-Türk Laikleşme Anlatısının Sorunları"; Anscombe. "Islam and the Age of Ottoman Reform".

75 See Yllmaz. Caliphate Redefined. 
Monica Ringer has argued that what distinguished the modern Islam of figures such as Namık Kemal or Al-Afghani was an emergent "historicism" which identified certain elements of religion as historically contingent and a quest for an essence of religion that was above history. ${ }^{76}$ While agreeing with Ringer, I would also argue that the emergence of this "historicism" predated both the Young Ottomans and modernist thinkers of Arab Nahḍah. The confluence of religious revival and socio-political reform in the Ottoman context had already triggered similar lines of questioning which led Ottoman reformers to historicize some of the basic tenets and foundations of their political system and return to Islam for a non-historical, immutable essence, a trove of moral principles. This growing historicist consciousness is the missing link between the early nineteenth century reform attempts and the Islamic modernism of the late nineteenth century. While the late nineteenth-century formulations betray virtually no recognition of the earlier debates over renewal, Young Ottomans would still propose a progressive narrative of reform starting with the seventeenth century and building up to the Tanzimat, representing greater political maturity towards a more representative regime in congruence with the "essence" of Islam. ${ }^{77}$ How this historicist hermeneutics of Islam has come to be replaced with more fundamentalist interpretations in the twentieth century remains a question to be addressed for the future scholarship.

\section{Acknowledgments}

This article is based partly on my PhD dissertation "From Decline to Progress: Ottoman Concepts of Reform 16oo-1876" defended at Bilkent University in 2017. This article is also part of my project "Messianic Conceptions of Politics and Authoritarianism in Turkey 1850-2015" which has received funding from the European Union's Horizon 2020 research and innovation programme under the Marie Skłodowska-Curie grant agreement No. 845625. I would like to thank Einar Wigen, Özgür Türesay and Mary Elston as well as the organizers and attendants of the workshop "The Multiple Times of Renaissances: revolutions, translations, movement of ideas across 19th-century Southeastern Europe and the Mediterranean" for their invaluable comments and suggestions.

76 Ringer, Islamic Modernism and the re-Enchantment of the Sacred in the Age of History.

77 See for instance Ali Suavi. "Terakki," Ittihâd, 1, May 15, 1869 in Çelik, Ali Suavi. 18o-83; and Ziya Paşa's series of articles on Ottoman reform in Topal (ed.), Sürgünde Muhalefet: Namık Kemal'in Hürriyet Gazetesi. 325-29, 370-76, 456-6o. 


\section{Bibliography}

Abu-Manneh, Butrus. "The Naqshbandiyya-Mujaddidiyya in the Ottoman Lands in the Early 19th Century”. Die Welt Des Islams, 22 (1984), p. 1-36.

Abu-Manneh, Butrus. "The Islamic Roots of Gülhane Rescript”. Die Welt des Islams, 34, 2 (1994), p. 173-203.

Abu-Manneh, Butrus. "Salafiyya and the Rise of the Khālidiyya in Baghdad in the Early Nineteenth Century”. Die Welt des Islams, 43:3 (2003), p. 349-372.

Abu-Manneh, Butrus. "Sheikh Murād al-Bukhārī and the Expansion of the Naqshbandī-Mujaddidī Order in Istanbul”. Die Welt des Islams, 53:1 (2013), p. 1-25.

Aksan, Virginia H. An Ottoman Statesman in War and Peace: Ahmed Resmi Efendi 170o1783. Leiden, Brill, 1985.

Aksan, Virginia H. "Ottoman Political Writing 1768-1808”. International Journal of Middle East Studies, 25 (1993), p. 53-69.

Anscombe, Frederick F. "Islam and the Age of Ottoman Reform". Past and Present, 208, 1 (2010), p. 159-189.

Badem, Candan. "The Question of the Equality of Non-Muslims in the Ottoman Empire during the Crimean War (1853-1856)". In: Jerzy W. Borejsza (ed.). The Crimean War 1853-1856 Colonial Skirmish or Rehearsal for World War? Empires, Nations, and Individuals. Warsaw, Wydawnictwo Neriton, 2011, p. 79-9o.

Berkes, Niyazi. The Development of Secularism in Turkey, Reissue edition. New York, Routledge, 1999.

Beydilli, Kemal. “Küçük Kaynarca'dan Tanzimat'a Islahat Düşüncesi”. Ilmi Araştırmalar, 8 (1999), p. 25-64.

Bouquet, Olivier. "Is it Time to Stop Speaking about Ottoman Modernization?". In: M. Aymes, B. Gourisse and É. Massicard (eds.). Order and Compromise: Government Practices in Turkey from the Late Ottoman Empire to the Early 21st Century. Leiden, Brill, 2015, p. 45-67.

Brisku, Adrian. Political Reform in the Ottoman and Russian Empires: A Comparative Approach. London, Bloomsbury, 2017.

Çağman, Ergin. III. Selim'e Sunulan Islahat Layihaları. Istanbul, Kitabevi, 2010.

Çelik, Hüseyin. Ali Suavi. Ankara, Kültür Bakanlığı, 1993.

Dallal, Ahmad. Islam without Europe: Traditions of Reform in Eighteenth-Century Islamic Thought. University of North Carolina Press, 2018.

Doğan, Lutfi. Keçecizāde Izzet Molla’nın Islah-ı Nizām-ı Devlete Dāir Risāle Adlı Eserinin Transkripsiyonu ve Edisyon Kritiği, MA Thesis, Istanbul University, 2000.

Erginbaş, Vefa (ed.). Ottoman Sunnism: New Perspectives. Edinburgh University Press, 2019.

Es’ad Efendi. Üss-i Zafer: Yeniçeriliğin Kaldırılmasına Dair. M. Arslan (ed.). Istanbul, Kitabevi, 2005 . 
Felek, Özgen. "(Re)creating Image and Identity: Dreams and Visions as a Means of Murad III's Self-fashioning”. In: Ö. Felek and A.D. Knysh (eds.). Dreams and Visions in Islamic Societies. Albany, SUnY Press, 2012, p. 249-272.

Fleischer, Cornell. "The Lawgiver as Messiah: The Making of the Imperial Image in the Reign of Süleymān". In: Gilles Veinstein (ed.). Soliman le magnifique et son temps. Paris, La Documentation Française, 1992, p. 159-177.

Gürpınar, Doğan. Ottoman/Turkish Visions of the Nation 1860-1950. Basingstoke, Palgrave Macmillan, 2013.

Haj, Samira. Reconfiguring Islamic Tradition: Reform, Rationality, and Modernity. Stanford, Stanford University Press, 2009.

Haykel, Bernard. Revival and Reform in Islam: The Legacy of Muhammad al-Shawkānī. Cambridge, Cambridge University Press, 2003.

Ilıcak, Şükrü. A Radical Rethinking of Empire: Ottoman State and Society During the Greek War of Independence (1821-1826). PhD Thesis, Harvard University, 2011.

Karpat, Kemal. Politicization of Islam: Reconstructing Identity, State, Faith, and Community in the Late Ottoman State. Oxford, Oxford University Press, 2001.

Kırmızı, Abdülhamid. "19. Yüzyılı Laiksizleştirmek: Osmanlı-Türk Laikleşme Anlatısının Sorunları". Cogito, 94 (2019), p. 93-109.

Koçunyan, Aylin. Negotiating the Ottoman Constitution 1839-1876. Louvain, Peeters, 2018.

Krstic, Tijana. Contested Conversions to Islam: Narratives of Religious Change in the Early Modern Ottoman Empire. Stanford, Stanford University Press, 2011.

Kuşmānī, Dihkanizade Ubdeydullah. Zebīre-i Kuşmānī fi Nizām-ı Ilhāmī, ed. Ö. Işbilir. Ankara, TTK, 2006.

Landau-Tasseron, Ella. “The 'Cyclical Reform': A Study of the mujaddid tradition”. Studia Islamica, 70 (1989), p. 79-117.

Mardin, Şerif. The Genesis of Young Ottoman Thought: A Study in the Modernization of Turkish Political Ideas. New York, Syracuse University Press, 2000.

Menchinger, Ethan L. An Ottoman Historian in an Age of Reform: Ahmed Vasif Efendi (ca. 173-1806), PhD Thesis, University of Michigan, 2014.

Menchinger, Ethan L. "Free Will, Predestination, and the Fate of the Ottoman Empire". Journal of the History of Ideas, 77, 3 (2016), p. 445-466.

Menchinger, Ethan L. The First of the Modern Ottomans: The Intellectual History of Ahmed Vasıf. Cambridge, Cambridge University Press, 2017.

Menchinger, Ethan L. "Dreams of Destiny and Omens of Greatness: Exceptionalism in Ottoman Political and Historical Thought”. Journal of Islamic Studies, 31, 1 (2020), p. 1-30.

Onaran, Burak. Padişahı Devirmek: Osmanlı Islahat Çağında Düzen ve Muhalefet: Kuleli (1859), Meslek (1867). Istanbul, Iletişim, 2018.

Porter, James. Turkey: Its History and Progress. London, Hurst and Blackett, 1854. 
Rahman, Fazlur. "Revival and Reform in Islam". In: P.M. Holt, K.S. Lambton, and B. Lewis (eds.). Cambridge History of Islam. Vol II. Cambridge, Cambridge University Press, 1970, p. 632-42.

Ringer, Monica M. Islamic Modernism and the re-Enchantment of the Sacred in the Age of History. Edinburgh, Edinburgh University Press, 2020.

Şakul, K. "Nizām-ı Cedid Düşüncesinde Batılılaşma ve Islami Modernleşme”. Divan, 19 (2005), p. 117-15o.

Sarıcaoğlu, Fikret. "Osmanlı Muhalefet Geleneğinde Yeni Bir Dönem: Ilk Siyasī Bildiriler”. Belleten, 241 (Dec 2000), p. 901-920.

Sarıkaya, Ahmet. Ömer Fāik Efendi, Nizāmü'l-Atik, Senior Thesis. Istanbul Universitesi Edebiyat Fakültesi Tarih Bölümü, 1979.

Sariyannis, Marinos. A History of Ottoman Political Thought up to the Early Nineteenth Century. Leiden, Brill, 2019.

Sariyannis, Marinos. "Ottoman Ibn Khaldunism Revisited: the Pre-Tanzimat Reception of the Muqaddima, from Kınalızade to Şanizade”. In: M. Sariyannis (ed.). Political Thought and Practice in the Ottoman Empire. Rethymno, Crete University Press, 2019, p. 251-286.

Shaw, Stanford J. Between the Old and the New: the Ottoman Empire Under Sultan Selim III, 1789-1807. Cambridge, Harvard University Press, 1971.

Şimşek, Veysel. The Grand Strategy of the Ottoman Empire 1826-1841. PhD Thesis, McMaster University, 2015.

Şiviloğlu, Murat R. The Emergence of Public Opinion: State and Society in the late Ottoman Empire. New York, Cambridge University Press, 2018.

Spannaus, Nathan. Preserving Islamic Tradition: Abū Nasr Qursāwī and the Beginnings of Modern Reformism. New York, Oxford University Press, 2019.

Topal, Alp Eren. From Decline to Progress: Ottoman Concepts of Reform 16oo-1876. PhD Thesis, Bilkent University, 2017.

Topal, Alp Eren (ed.). Sürgünde Muhalefet: Namık Kemal'in Hürriyet Gazetesi. Istanbul, VBKY, 2019.

Topal, Alp Eren. "Ottomanism in History and Historiography: Fortunes of a Concept". In: Johanna Chovanec and Olof Heilo (eds.) Narrated Empires: Perceptions of Late Habsburg and Ottoman Multinationalism. Cham, Palgrave Macmillan, 2021, p. 77-98.

Topal, Alp Eren and Wigen, Einar. "Ottoman Conceptual History: Challenges and Prospects". Contributions to the History of Concepts, 14, 1 (2019), p. 93-114.

Türesay, Özgür. "The Political Language of Takvim-i vekayi: the Discourse and Temporality of Ottoman 'Reform' (1831-1834)". European Journal of Turkish Studies, $31(2020)$.

Voll, John O. "Renewal and Reform in Islamic History: Tajdid and Islah". In:John Esposito (ed.). Voices of Resurgent Islam. Oxford, Oxford University Press, 1983, p. 322-45. 
Yaycıoğlu, Ali. "Guarding Traditions and Laws — Disciplining Bodies and Souls: tradition, science, and religion in the age of Ottoman reform". Modern Asian Studies, 52, 5 (2018), p. 1542-16o3.

Yeşil, Fatih. "Looking at the French Revolution through Ottoman eyes: Ebubekir Ratib Efendi's observations". Bulletin of the School of Oriental and African Studies, 70, 2 (2007), p. 283-304.

Yıldız, Gültekin. Neferin Adı Yok: Zorunlu Askerliğe Geçiş Sürecinde Osmanlı Devletinde Siyaset, Ordu ve Toplum (1825-1839). Istanbul, Kitabevi, 2009.

Yllmaz, Hüseyin. Caliphate Redefined: The Mystical Turn in Ottoman Political Thought. Princeton; Oxford, Princeton University Press, 2018. 